\title{
The experience of conditional cash transfers Lessons for REDD+ benefit sharing
}

\author{
Grace Wong
}

\section{Key lessons}

- Conditionality is a key element of conditional cash transfer (CCT) programs and its use has broad political and social appeal. The use of intermediate indicators for ease of implementing conditionality and monitoring (e.g. school enrollment or visits to the clinic) may not fully capture the desired long-term outcomes (e.g. learning achievement or health indicators). The parallel for REDD+ is in choosing between simpler input-based conditionality indicators (e.g. number of trees planted, number of monitoring surveys carried out) or long-term outcome-based indicators (e.g. forest cover maintained, amount of carbon emissions reduced).

- Conditionalities can create substantive costs and there is mixed evidence on their effect. Their relevance and feasibility depend on contextual factors such as politics, and the feasibility, desirability and capacity of countries to set and monitor conditions.

- CCT programs often experience tension between efficiency and equity, where more complex eligibility criteria to ensure equity outcomes will entail higher costs to implement and to monitor. There is a similar tension for REDD+ in realizing objectives for effectiveness (e.g. households who are eligible based on their expected deforestation behavior) and equity (e.g. reaching the poorest households).

- Additionality is an important component of CCT programs, and there is some evidence of positive spillovers on the behavior and consumption of households that do not receive the transfer. The magnitude of these spillovers depends on uptake rates, counterfactual compliance and distribution of the opportunity costs of compliance. For REDD+, there is a risk of negative spillovers if targeting is perceived as unfair, particularly by those who may be non-eligible because of the non-additionality of their behavior before payments (e.g. forest stewards).

- The effect of additional cash inflows into a household economy has in some cases led to changes in consumption preferences that can have a negative impact on the environment, and in the case of REDD+, this could result in displacement of forest degradation activities elsewhere.

- Evidence from CCT programs suggests that packaging complementary measures may be an effective way to address multiple goals of improved health and education outcomes with poverty alleviation and resilience to risks. The potential for linking REDD+ with social measures is an attractive solution to avoid over-burdening the REDD+ agenda.

\section{Introduction}

Incentives conditioned on socially desired actions have increased in popularity, and conditional cash transfer (CCT) programs have been widely applied in recent decades. These social programs generally transfer cash to poor households on the condition that the households make specific investments in human and social capital. Nancy Birdsall, President of the Center for Global Development, claimed that "... these programs are as close as you can come to a magic bullet in development. They are creating an incentive for families to invest in their own children's futures. Every decade or so, we see something that can really make a difference, and this is one of those things" (De Janvry and Sadoulet 2004). REDD+ is fashioned after such conditional incentives, as a performance-based mechanism that provides compensation to developing countries and groups for fully measured, reported and verified carbon emissions reductions (Wertz-Kanounnikoff and Angelsen 2009).
The popularity of CCT programs can be attributed to the successes of the Bolsa Escola (later merged into Bolsa Família) in Brazil and Progresa (renamed Oportunidades) in Mexico in the 1990s. Both the Bolsa Família and Oportunidades now form the backbone of national social security policy, serving a quarter of the countries' populations with budgets of about $0.5 \%$ of gross domestic product (Fiszbein and Schady 2009). CCT programs are often not the only cash transfer program within a country's social protection or poverty reduction strategy (DFID 2011; World Bank 2012). CCT programs tend to emphasize future poverty reduction through human capital development (Samson et al. 2010) and are typically implemented in hand with other programs that focus on immediate poverty reduction goals.

Political economy considerations are one important factor favoring conditional transfers - policy makers tend to view CCT as more politically acceptable to voters and taxpayers because 
it dilutes the negative (and often misguided) perceptions of dependence with positive sentiments of responsibility, and more politically attractive deliverables of health and education. Successive governments in several countries (e.g. Brazil, Mexico) have demonstrated willingness to continue and expand program coverage (Fiszbein and Schady 2009).

While there is fairly clear empirical support that CCT programs have attended to the poorest of the poor, been administratively efficient and reduced inequality, there is weaker evidence that they have achieved the desired impacts or outcomes of increasing accumulation of human capital, and breaking intergenerational poverty (Rawlings and Rubio 2003; Valencia Lomeli 2008). CCTs have not been around long enough to measure the long-term generational outcomes that would be the result of a focus on children's health and education, and quantifying the more intangible social and cultural impacts is difficult. The 'pyramid of suppositions' upon which CCT programs are constructed still leaves many uncertainties (Valencia Lomeli 2008) and these suppositions are examined to identify relevant lessons for REDD+ benefit sharing.

\section{Identifying lessons from CCT programs for REDD+}

Environmental financing, such as payment for environmental services (PES) and REDD+ instruments, is part of the broader family of conditional transfer instruments. The commonality between CCTs, PES and REDD+ is that they all offer positive incentives conditional on a certain behavior, linked to investments in either social or environmental capital, as a way to address specific market failures (Pattanayak et al. 2010; Rodriguez et al. 2011; Persson and Alpizar 2013). CCT corrects for underinvestment in human and social capital, while PES and REDD+ aim to correct for market failures that lead to excessive levels of environmental and forest degradation.

Throughout this paper, we examine key elements of CCT programs to draw out the lessons for REDD+: (i) the effects of conditionality (how important is the condition in accounting for the outcomes of conditional cash transfer programs?); (ii) the impact of cash transfers on household decisions; and (iii) the targeting of beneficiaries (how can additionality effects be maximized and negative behavioral spillovers minimized?). We look at effectiveness, efficiency and equity (3Es), and their tradeoffs to identify lessons for REDD+ on how different structural or design aspects of the programs can influence outcomes.

\section{What can be said about CCT impacts?}

Many CCT programs are implemented at the national level and are co-financed by government budgets and development aid funding. The pioneering Latin American CCT programs have had built-in rigorous monitoring and evaluation (M\&E) systems since their inception, driven in part by international donor demand (DFID 2011). In general, the body of M\&E results has generated evidence that large-scale CCT programs are technically feasible, have been generally well targeted and improved the lives of poor people, with positive impacts on schooling, health, infant mortality, consumption and child labor (see Table 1 for summary of impacts). Fiszbein and Schady (2009) argue that CCT programs have provided an entry point to reforming badly targeted subsidies and upgrading the quality of safety nets.
There is some evidence that CCT programs have reduced inequality. Soares et al. (2007) found that CCT programs were responsible for an equalizing impact of about $21 \%$ of the fall in both the Brazilian and Mexican Gini index, and a more modest $15 \%$ reduction in Chile. This startling effect is attributed to the strong effort made in targeting poor and vulnerable beneficiaries.

However, many of the expected positive effects have also failed to materialize, e.g. Bolsa Família has had very little impact on nutrition improvements and Program Keluarga Harapan (PKH) in Indonesia had no impact on school enrollment or dropout rates. In the case of Progresa, the positive impact on child growth cannot be solely attributed to cash transfers since families also received nutritional supplements through separate programs (Fiszbein and Schady 2009).

\section{Basic characteristics of conditional cash transfer programs}

\section{Why conditionality?}

Economic rationale suggests that there are market failures causing individuals or families to underinvest in human or social capital (Das et al. 2005; Fiszbein and Schady 2009). A CCT program, thus, addresses the underlying market failure and in the process reconciles societal preferences and individual choices. In economic terms, CCTs seek to restore efficiency within the economy.

Conditionalities are designed to induce households to behave differently than they would have, had they just been given unconditional cash. From an economic perspective, CCT programs are effective because they create a price effect, not an income effect. The subsidies or incentives provided by CCT programs act like a price effect on the desired action: they are expected to induce individuals to increase their supply of the actions by raising the price for them.

Conditionality is key in recent forest conservation instruments such as REDD+, contrasting with the previous generation of integrated conservation and development projects (ICDPs)—where financing was unconditional and it was believed that most environmental problems could only be effectively addressed if poverty was alleviated through development activities. A documented weakness of ICDP programs is the tenuous conservation results, attributed in part to a lack of conditionality and focus (Pattanayak et al. 2010).

Much of the debate between conditional and unconditional transfers centers around whether poor households know how best to employ resources for household well-being, whether they have full information for their decisions, and whether they act accordingly (Samson et al. 2010). This clearly differs from the case of REDD+, which assumes that households are already making rational economic decisions about forest and land use, and the incentives act as compensation to change that behavior. However, within the CCT evidence base, it is difficult to distinguish whether impacts are due to the cash transfer, or whether they are due to the conditionality (Baird et al. 2011).

There is evidence supporting the use of conditionalities. When households in Ecuador and Mexico did not think that the cash transfer program was conditional on school attendance, school 
Table 1: Best known CCT programs and evaluations of their impacts

\begin{tabular}{|c|c|c|c|c|}
\hline $\begin{array}{l}\text { Program } \\
\text { (country) }\end{array}$ & $\begin{array}{l}\text { Budget } \\
\text { (USD) and } \\
\text { coverage }\end{array}$ & Origin & Conditionality & Main evaluation findings \\
\hline \multirow{3}{*}{ 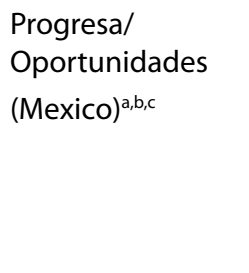 } & \multirow{3}{*}{$\begin{array}{l}\text { USD } 2.8 \text { billion; } \\
5 \text { million } \\
\text { households ( } 3.5 \\
\text { million rural) } \\
(2004)\end{array}$} & \multirow{3}{*}{$\begin{array}{l}\text { Federal government } \\
\text { stand-alone } \\
\text { program began in } \\
\text { 1997, coinciding } \\
\text { with removal } \\
\text { of general food } \\
\text { subsidies }\end{array}$} & \multirow{3}{*}{$\begin{array}{l}\text { School enrollment; } 85 \% \\
\text { attendance on monthly/ } \\
\text { annual basis. Health center } \\
\text { visits and seminars ( } 2-4 \\
\text { annually per child, } 1 \text { per } \\
\text { adult and } 7 \text { pre- and post- } \\
\text { natal checkups per woman) }\end{array}$} & Positive impact on child growth \\
\hline & & & & $\begin{array}{l}\text { Small improvements in primary } \\
\text { attendance rates, larger } \\
\text { improvements for secondary school }\end{array}$ \\
\hline & & & & $\begin{array}{l}\text { Reduction in poverty gap by } \\
\text { approximately } 20 \%^{\mathrm{d}}\end{array}$ \\
\hline \multirow[t]{4}{*}{$\begin{array}{l}\text { Bolsa Família } \\
\text { (Brazil) })^{\mathrm{a}, \mathrm{b}, \mathrm{c}}\end{array}$} & \multirow{4}{*}{$\begin{array}{l}\text { USD2.1 billion; } \\
8 \text { million } \\
\text { households } \\
\text { (2004) }\end{array}$} & \multirow{4}{*}{$\begin{array}{l}\text { Merger of several } \\
\text { programs (Bolsa } \\
\text { Escola, Bolsa } \\
\text { Alimentação, Auxílio } \\
\text { Gás and Cartão } \\
\text { Alimentação) into } \\
\text { one in } 2004\end{array}$} & \multirow{4}{*}{$\begin{array}{l}\text { Enrollment and attendance } \\
\text { of children in primary } \\
\text { and secondary school. } \\
\text { Reproductive health } \\
\text { education and family } \\
\text { planning. Child vaccination, } \\
\text { growth monitoring, } \\
\text { nutritional supplements and } \\
\text { health care measures }\end{array}$} & $\begin{array}{l}8 \% \text { reduction in poverty, } 18 \% \text { in } \\
\text { poverty gap and } 22 \% \text { in severity of } \\
\text { poverty }^{d}\end{array}$ \\
\hline & & & & $\begin{array}{l}\text { Ex-ante increases in school } \\
\text { enrollment, but no effect on current } \\
\text { poverty levels }\end{array}$ \\
\hline & & & & $\begin{array}{l}\text { Unconditional cash transfers would } \\
\text { have no impact on child labor and } \\
\text { school enrollment }\end{array}$ \\
\hline & & & & No impact on nutritional gains \\
\hline \multirow{3}{*}{$\begin{array}{l}\text { Program } \\
\text { Keluarga Harapan } \\
\text { (Indonesia) })^{\mathrm{e}, \mathrm{f}}\end{array}$} & USD228 million; & \multirow{3}{*}{$\begin{array}{l}\text { Began in } 2007 \text { as } \\
\text { a pilot targeting } \\
\text { 'extremely poor' } \\
\text { households. } \\
\text { Coverage expanded } \\
\text { from } 7 \text { provinces in } \\
2007 \text { to } 33 \text { in } 2012\end{array}$} & \multirow{3}{*}{$\begin{array}{l}\text { Obtain preventive health } \\
\text { care (pre- and post- } \\
\text { natal care, professionally } \\
\text { attended birth, child } \\
\text { weighings) and nutritional } \\
\text { services. Child enrollment } \\
\text { and } 85 \% \text { attendance in } \\
\text { school }\end{array}$} & \multirow{3}{*}{$\begin{array}{l}\text { Program increased food consumption, } \\
\text { particularly high-protein foods, and } \\
\text { access to health facilities, but had } \\
\text { no impact on school enrollment or } \\
\text { dropout rates. There was also no } \\
\text { impact on reducing child labor }\end{array}$} \\
\hline & $\begin{array}{l}1.45 \text { million } \\
\text { households }\end{array}$ & & & \\
\hline & $(2012)$ & & & \\
\hline \multirow{3}{*}{$\begin{array}{l}\text { Juntos } \\
(\text { Peru })^{g}\end{array}$} & USD133 million & \multirow{3}{*}{$\begin{array}{l}\text { Began in } 2005 \\
\text { targeting poor } \\
\text { households with } \\
\text { children under } \\
\text { 14. Explicit focus } \\
\text { on groups most } \\
\text { affected by political } \\
\text { violence in 1980s } \\
\text { and 1990s. Transfer } \\
\text { is to mothers }\end{array}$} & \multirow{3}{*}{$\begin{array}{l}\text { Civic identification } \\
\text { documents for adults } \\
\text { and children. Vaccination, } \\
\text { health, pre- and post- } \\
\text { natal care, participation } \\
\text { in National Nutritional } \\
\text { Assistance Program. Use of } \\
\text { chlorinated water and anti- } \\
\text { parasitic medication }\end{array}$} & \multirow{3}{*}{$\begin{array}{l}\text { Immunization of children under } 1 \text { year } \\
\text { increased by } 30 \% \text {, pre- and post-natal } \\
\text { visits by } 65 \% \text {, and reduction in home } \\
\text { births. Increase in school attendance }\end{array}$} \\
\hline & $\begin{array}{l}\text { over 2005- } \\
2006\end{array}$ & & & \\
\hline & $\begin{array}{l}135,000 \\
\text { households } \\
\text { (September } \\
\text { 2006) }\end{array}$ & & & \\
\hline
\end{tabular}

a Das et al. (2005); ${ }^{b}$ Fitzbein and Schady (2009); ' Handa and Davis (2006); ' Soares (2012); e World Bank (2012); ' Nazara and Rahayu (2013); 9 Jones et al. (2008).

enrollment was significantly lower (Baird et al. 2011). According to Das et al. (2005), households in western Kenya who were given cash conditional on purchase of insecticide-treated bednets and had seen decreased incidences of malaria as a consequence, would still have chosen to spend the equivalent cash on other priorities (such as food and clothing) if given the choice.

Other studies suggest that cash transfers alone might be sufficient: this supports the theory that the poor are rational actors and easing cash constraints (an income effect) will result in increased investment in human capital without the need for conditions. Unconditional cash transfers (social pensions and child grants) have achieved measurable impacts on service use (e.g. school enrollments) and outcomes (e.g. child growth) in South Africa (DFID 2011). Blattman et al. (In press) provided evidence that recipients (unemployed youths) in Uganda receiving cash transfers are likely to spend it on developing human capital and microfinance formation.

An experimental study from Malawi compared a control group with (i) a group that received CCTs, and (ii) a group that received unconditional cash transfers (UCT). The study found that the reduction in school dropout rate in the CCT group was twice as large as that in the UCT group (Baird et al. 2011). A more recent systematic review provided global evidence that while both CCT and UCT improve the odds of children being in school (23\% for UCT programs and $41 \%$ for CCT programs), conditions do seem to cause further increases in program impacts (Baird et al. 2013). However, Özler (2013) argued that people who receive UCTs may be better off even though they have less schooling than those given CCTs, because their choice sets are larger-and welfare cannot be lower when choice sets are larger. 
This debate is not inconsequential as conditionalities create substantive costs for governments, who must monitor compliance, and for recipients, who must demonstrate it. Monitoring conditionality in the Oportunidades program represented about $18 \%$ of the total costs, net of transfers (Handa and Davis 2006). In Indonesia's PKH, administrative costs for implementing health CCTs represent $18 \%$ of the program budget, compared to $8 \%$ for UCTs - the difference equivalent to supporting an additional 100,000 beneficiaries (Febriany and Suryahadi 2012)

The choice and selection of conditionalities and their monitoring involves trading off simplicity against impact (Samson et al. 2010), or in other words, efficiency against effectiveness. There are at least four different types of outcomes that CCTs may affect: (i) intermediate use indicators, such as school enrollment and attendance, or visits to health centers; (ii) 'final outcomes' in human capital accumulation, such as learning achievement or improved health; (iii) short-run welfare, which may be captured by family income and expenditures; and finally (iv) long-term welfare, which may be measured by the child's future income, well-being and happiness (Özler and Ferreira 2011). Simple conditionality involves discrete choices, such as school enrollment, and using school enrollment registries as a monitoring and verification mechanism is relatively easy and inexpensive. A more effective conditionality might require monitoring of continuous decisions, such as school attendance over time. More demanding and consequently, more costly and challenging for monitoring and verification is evaluation of outcomes such as educational performance or nutritional impact on health (Samson et al. 2010; DFID 2011). The long-term welfare impacts will require generational monitoring. Unsurprisingly, most of the evidence from CCT evaluations refers to category (i) indicators.

With REDD+, conditionality generally relates to a change in behavior of a beneficiary, such as not clearing forests for agriculture or planting trees, and the monitoring system is related to carbon emissions - typically measured by forest cover. The advantage of this is that the behavior change is tied to a long-term outcome such as forest cover, but the challenge is in attribution. Broad scale monitoring might not adequately capture the attribution of the beneficiaries' actions, for example if forest clearing is being carried out elsewhere within the landscape (leakage), or if the trees that are planted as a condition for payment are not maintained properly.

\section{The cash effect}

Although direct cash transfers have opportunity costs (in terms of forgone alternative public investments) and may have some perverse incentive effects on recipients, there is evidence to suggest that they may be more flexible, efficient and effective than other in-kind transfers (Fiszbein and Schady 2009). CCT programs in rural areas constitute a substantial infusion of liquidity among poor households and their communities, and evidence from Mexico and Nicaragua suggests that even the extreme poor spend part of their cash transfers on productive activities (Handa and Davis 2006; Fiszbein and Schady 2009). Welldesigned and implemented programs with a pattern of fixed, regular and predictable transfers are shown to help strengthen household productivity even if that was not the main objective (Pagiola 2008; DFID 2011).
An influx of cash, however, can also have unintended consequences - and these are important lessons for REDD+. A study of Oportunidades households in Mexico found that the additional income from cash transfers raises consumption of land-intensive goods (beef and milk) and the additional demand increases deforestation - a response that is more prominent in communities with poor road infrastructure (Alix-Garcia et al. 2013). Some CCT evaluations found that distribution of cash grants directly to mothers negatively affected intra-household resource allocations and power relations. Cash transfers may also negatively affect community relations, when some but not all members of a community receive benefits (Rawlings and Rubio 2003).

The impact of CCTs on consumption and poverty could be offset if they crowd out remittances and other traditional forms of transfers received by households (such as informal insurance, intra-community transfers and kinship gifts) and these may affect household risk and coping strategies (Rawlings and Rubio 2003; Fiszbein and Schady 2009). Nielsen and Olinto (2008) found that while the prevalence and amount of remittances in Honduras and Nicaragua were unaffected by CCTs, there is evidence of crowding out of food and money transfers from private sources and nongovernmental organizations, which is a concern as they represent informal insurance schemes.

The literature on work disincentive effects of social assistance programs is vast for developed countries, but there is little evidence available of this effect for CCT programs (Fiszbein and Schady 2009). There is some evidence from Bolsa Família that its impact on the labor market is even positive, at least for working-age men, as cash transfers are used to cover the costs associated with job seeking (Soares 2012).

\section{Managing trade-offs between efficiency and equity}

The first economic rationale for a CCT program is to reconcile societal preferences and individual choices and restore efficiency within the economy (as discussed in the previous section). A second economic rationale for CCT programs is to achieve equity outcomes in targeting and pro-poor redistribution of resources (Das et al. 2005). Much of the empirical literature on CCT programs focuses on the two rationales, but there can be tension between the efficiency and equity objectives. One example of a CCT program that is efficient but not equitable is the Female Stipend program in Bangladesh (Das et al. 2005). The program aimed to increase school enrollment of girls and provide stipends to those who attended at least $85 \%$ of classes, without any eligibility criteria besides attendance. Results showed that girls' enrollment rates increased substantially, but the program had adverse redistributive effects as richer households were more likely than poor households to enroll their children and stipends went disproportionately to girls from households with larger land wealth. These trade-offs are not new to policy makers however.

Many CCT programs attempt to address equity by constructing eligibility criteria to better target the beneficiary groups (Das et al. 2005). These can range from measures such as household income (e.g. Bolsa Familia provides cash to households with per capita monthly incomes less than BRL90, or USD36) to correlates of poverty, such as lack of land ownership or unemployment (as used in the Food for Education program in Bangladesh). 
The efficiency versus equity trade-off in REDD+ is perhaps more challenging. Efficiency in REDD+ would mean that incentives are best directed to those beneficiaries who can reduce emissions at least cost, and in many countries these may be large private landowners or industrial land concession holders (Luttrell et al. 2013; Pham et al. 2013). However, as equity considerations are equally important, channeling REDD+ incentives to smallholders or to the poor may be a legitimate eligibility or targeting criteria for certain objectives and country contexts.

\section{Targeting for additionality and consequences of behavioral spillovers}

One measure of success for a CCT program is the extent to which it induces additional investments in human or environmental capital, over and beyond what would have occurred in the absence of the program incentives. Additionality is also an essential element of REDD+ (Persson and Alpizar 2013). Since all programs operate on a limited budget and are driven by some political motivation, increasing additionality is seen as necessary for effectiveness and impact.

Persson and Alpizar (2013) suggests that additionality can benefit from a deeper understanding of the determinants of, and take-up rates among eligible households, and the effect of targeting and differentiating payments, for example, based on actual opportunity costs incurred. However, this has to be weighed against the economic and political costs of targeting and differentiation. If a program's main purpose is to transfer resources to the poor, then increasing and targeting payments (potentially reducing the number of beneficiaries) to achieve higher additionality may not be acceptable. On the other hand, it may still be acceptable if the change in distribution is progressively towards the poor (De Janvry and Sadoulet 2006). Similarly in the case of REDD+, focus on additionality of carbon emissions will direct incentives to change the behavior of only those who are expected to affect forests, thus creating a potential trade-off with equity.

An interesting strand of research in CCT programs is on positive spillover impacts of cash transfers on the behavior and consumption of households living in the same village that do not receive the transfer (ineligible households). The presence of Indonesia's PKH for example has led to increased pre-natal visits and child weighings in substantive numbers of non-beneficiary households living in PKH areas (World Bank 2012). Results from analysis of data from Mexico's Progresa suggest that these positive spillover effects are pro-poor, in that the increase in food consumption is greater in poorer ineligible households than in 'better off' ineligible households (Lehmann 2010). Similarly, Bobonis and Finan (2009) find a 5 percentage-point increase in secondary school enrollment among children from ineligible households in villages where Progresa is implemented, and the increase also has pro-poor implications. However, these are still emerging findings from a fraction of CCT programs being implemented.

In the conservation sector, there is emerging evidence of negative behavioral spillovers when targeting is perceived to be unfair (Alpizar et al. 2013; Norden et al. 2013). Alpizar et al. (2013) provide empirical evidence that stakeholders who are excluded from conservation incentives may choose to act in less socially desirable ways than before the incentive was introduced. This unintended effect of exclusion depended on the selection rule for the incentive. The criteria for additionality are to target areas where conservation would not occur without the incentive, and those groups who, in the absence of incentives, would make land use decisions contrary to the desired objective. This may result in 'behavioral leakage', where those excluded based on past socially desirable actions may choose to reduce their actions. This result has resonance for the ongoing debate as to who should benefit from REDD+. At the moment, the dominant rationale in many REDD+ countries is to direct REDD+ benefits to those who have the right to the forests or land, those whose actions are causing emissions and those who would incur a cost in changing behavior (Luttrell et al. 2013; Pham et al. 2013). Excluding the possibility of REDD+ payments to reward past forest conservation behavior may inadvertently create a perverse incentive effect and lead to unexpected negative spillovers. Table 2 presents a summary of the effectiveness, efficiency and equity effects of CCTs and the lessons for REDD+ benefit sharing.

\section{Table 2. CCT programs: 3Es outcomes and lessons for REDD+ benefit sharing}

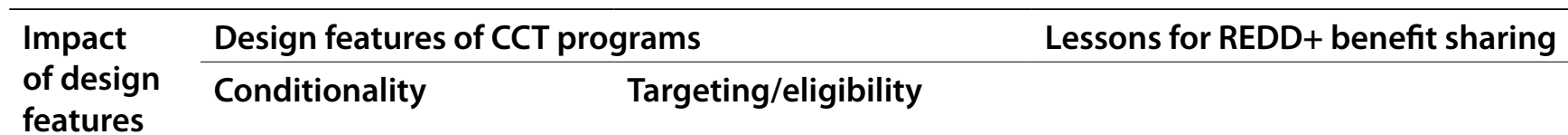

\section{features}

Effectiveness/ CCT programs have achieved outcomes measurable successes in reaching their stated objectives. In general, the conditionality indicators are designed to capture behavior change over the short term.

Measuring the longer term social capital outcomes or reduced intergenerational poverty is more challenging. It is also not always clear whether it is the conditionality or the cash flows that contribute to success, with mixed evidence for both.
The objective of CCTs is to reach the poorest or most vulnerable groups. Use of different targeting approaches and eligibility criteria (whether to be more stringent or generalized) will involve tradeoffs in costs and additionality. The best option is determined in part by the characteristics of the target groups (how the poor and vulnerable are defined), and perhaps more importantly by availability of data and funds, institutional capacity and political acceptability.
The effectiveness of REDD+ is measured by carbon emission outcomes, and rarely by indicators of social well-being, despite the social and equity objectives used in many REDD+ countries.

How REDD+ effectiveness will be measured informs the conditionality and targeting of eligible groups. Where there are multiple objectives for REDD+ (additionality and poverty reduction), then it becomes more complicated to have criteria for targeting (e.g. those who own land or forests in areas of high deforestation potential, and who are also poor). 
Table 2. continued

\begin{tabular}{lll}
\hline $\begin{array}{l}\text { Impact } \\
\text { of design } \\
\text { features }\end{array}$ & Design features of CCT programs & Lessons for REDD+ benefit sharing \\
\cline { 2 - 3 } & Conditionality & Targeting/eligibility
\end{tabular}

Efficiency/ Costs depend in large part on
cost the selection of conditionality and monitoring factors. The choice of simple versus complex conditionality factors and monitoring criteria (e.g. monitoring school registration versus class attendance and educational performance) affects both costs and ability to measure outcomes.

\section{More sophisticated and stringent criteria to ensure that the} targeted population is reached may be more effective in achieving desired impacts but will involve higher costs.

More stringent criteria may also create conflicts within a community when some but not all members of a community receive benefits.
The conditionality attached to existing pilot REDD+ projects is largely related to inputbased activities that are relatively easy to monitor (e.g. the number of trees planted or hectares reforested, or the number of monitoring surveys).

More sophisticated criteria to measure emission outcomes will depend on a national measuring, reporting and verification (MRV) infrastructure. An emerging area of concern is the lack of linkages between the flow of REDD+ finance and flow of carbon information in MRV systems. The institutional design for how the two systems fit will influence both effectiveness and efficiency aspects.

\begin{tabular}{ll}
\hline Equity & It is argued that CCTs are a \\
& trade-off with immediate \\
poverty reduction because & \\
their objectives are focused & on longer-term human capital \\
development goals.
\end{tabular}

Certain CCT programs have specifically targeted gender, e.g. females in their role as primary care-givers within households. Equity criteria may require setting eligibility criteria to ensure that cash transfers reach the targeted population.

REDD+ programs generally define the core target group as actors with legal land or forest owners, and/or those who would incur costs to change their forest- and land-use activities to provide for emissions reductions. This core group is sometimes extended to include, for example, the poorest, women-headed households or low-emitting forest stewards to meet other social and equity objectives.

Additionality is a selling point for REDD+.

Though not yet a widespread finding, positive spillover effects have been observed for noneligible households living in the same villages in certain contexts. Focusing REDD+ to bring about change in deforestation and forest degradation behaviors by compensating for the opportunity costs of those behaviors could exclude the actors who were already behaving positively in terms of forest management.

The consequence is the possibility of negative spillovers, as stakeholders who perceive themselves to be unfairly excluded may choose to act in a less socially desirable way than before the incentive was introduced.

\section{Discussion}

\section{Context}

The conditional aspect of CCT programs is one of their more attractive features and also one of the most complicated to execute. CCTs generally receive broad political support because they are seen as a social contract where society (through the state) supports poor households on the merit of their actions (Fiszbein and Schady 2009). There is mixed empirical evidence with which to judge the additional value of conditions, and the decision whether to use them will also have to take into account the influence of other contextual factors — such as politics, and the feasibility, desirability and capacity of countries to set conditions (DFID 2011). The administrative burden of monitoring conditionality, particularly in countries with weak institutional structures, has led to some debate over whether conditionality is necessary, and if it is, what type of monitoring mechanism is best, given costs and institutional structures and capacity (Handa and Davis 2006).

\section{CCT and REDD+ as complementary investments}

Özler (2013) suggests that even when CCTs are correcting a market failure, they may only be a second- or third-best solution because of the trade-offs between short-term poverty needs and the long-term development focus of a CCT program.

\footnotetext{
Many national programs and debates around REDD+ revolve around the need to include poverty reduction and other social objectives in the design of a REDD+ program. Evidence suggests that although transfers are small, the reliability of cash flows has helped poor households to accumulate productive assets, avoid distress sales, obtain access to credit on better terms and in some cases to diversify into higher return activities (DFID 2011). An analysis of panel data from 24,000 households in 506 villages in rural Mexico revealed that households receiving Progresa benefits were able to protect their consumption from fluctuations in income better than their counterparts in the control villages (Skoufias 2007). Similarly,
} 
there is some evidence that cash payments from PES programs have an increasing role in landholders' risk management strategy because fixed, regular and predictable payments can help to reduce income fluctuation when returns on crop production vary with weather and market conditions (Pagiola 2008).

Macours et al. (2012) provide evidence from Nicaragua that combining CCT with complementary training and productive interventions can help households manage short-term risks and protect food consumption against weather shocks, and create the ability to undertake longer term adaptive practices.

The potential for integrating different measures to address multiple objectives has resonance for REDD+, which has often been burdened as a 'win-win' solution for environmental conservation and poverty reduction objectives and could in effect turn out to be 'win-settle' (Wunder 2013). The potential for linking REDD+ with CCT and other existing social measures will depend on overlapping geographies and require stringent targeting criteria to be able to achieve its multiple objectives (Rodriguez et al. 2011). Packaging REDD+ with CCT and other social protection measures may be an alternative to diluting the REDD+ agenda and could leverage administrative synergies across cash transfer programs.

\section{Acknowledgements}

The author gratefully acknowledges funding received from the European Commission, Norwegian Agency for Development Cooperation (Norad) and the Australian Agency for International Development (AusAID). I am also grateful to Cecilia Luttrell, Sven Wunder, Elena Petkova, Lasse Loft and Anastasia Yang, whose critical remarks have helped to improve this infobrief.

\section{References}

Alix-Garcia J, McIntosh C, Sims KR and Welch JR. 2013. The ecological footprint of poverty alleviation: Evidence from Mexico's Oportunidades program. Review of Economics and Statistics 95(2):417-35.

Alpizar F, Norden A, Pfaff A and Robalino J. 2013. Effects of exclusion from a conservation policy: Negative behavioral spillovers from targeted incentives. Duke Environmental and Energy Economics Working Paper EE 13-06. Durham, North Carolina, USA: Nicholas Institute for Environmental Policy Solutions and the Duke University Energy Initiative.

Baird S, Ferreira FHG, Özler B and Woolcock M. 2013. Relative effectiveness of conditional and unconditional cash transfers for schooling outcomes in developing countries: A systematic review.

Oslo, Norway: Campbell Systematic Reviews. doi: 10.4073/csr.2013.8.

Baird S, Mclntosh C and Özler B. 2011. Cash or condition? Evidence from a cash transfer experiment. Quarterly Journal of Economics 126:1709-53.

Blattman C, Fiala N and Martinez S. In press. Generating skilled self-employment in developing countries: Experimental evidence from Uganda. Quarterly Journal of Economics.

Bobonis GJ and Finan F. 2009. Neighborhood peer effects in secondary school enrollment decisions. Review of Economics and Statistics 91(4):695-716.

Das J, Do QT and Özler B. 2005. Reassessing conditional cash transfer programs. World Bank Research Observer 20(1):57-80.

De Janvry A and Sadoulet E. 2004. Conditional cash transfer programs: Are they really magic bullets? Agricultural and Resource Economics Update 6:9-11.
De Janvry A and Sadoulet E. 2006. Making conditional cash transfer programs more efficient: Designing for maximum effect of the conditionality. World Bank Economic Review 20(1):1-29.

DFID. 2011. DFID cash transfers. Evidence paper. London, UK: Department for International Development.

Febriany V and Suryahadi A. 2012. Lessons from cash transfer programs in Indonesia. East Asia Forum. Accessed 2 October 2014. http://www.eastasiaforum.org/2012/07/21/lessons-fromcash-transfer-programs-in-indonesia/.

Fiszbein A and Schady N. 2009. Conditional cash transfers: Reducing present and future poverty. World Bank Policy Research Report. Berlin, Germany: Springer.

Handa S and Davis B. 2006. The experience of conditional cash transfers in Latin America and the Caribbean. Development Policy Review 24(5):513-36.

Jones N, Vargas R and Villar E. 2008. Cash transfers to tackle childhood poverty and vulnerability: An analysis of Peru's Juntos Programme. Environment and Urbanization 20:255-73.

Lehmann C. 2010. Benefiting without receiving money? Externalities of conditional cash transfer programmes on schooling, health and the village economy. Policy Research Brief 3. Brasilia, Brazil: International Policy Center for Inclusive Growth.

Luttrell C, Loft L, Gebara MF, Kweka D, Brockhaus M, Angelsen A and Sunderlin WD. 2013. Who should benefit from REDD+? Rationales and realities. Ecology and Society 18(4):52.

Macours K, Premand P and Vakis R. 2012. Transfers, diversification and household risk strategies: Experimental evidence with lessons for climate change adaptation. Policy Research Working Paper 6053. Washington, DC: World Bank.

Nazara S and Rahayu SK. 2013. Program Keluarga Harapan (PKH): Indonesian conditional cash transfer programme. Policy Research Brief 42. Brasilia, Brazil: International Policy Center for Inclusive Growth.

Nielsen ME and Olinto P. 2008. Experimental effect on the crowdingout effect of conditional cash transfers. Washington, DC: World Bank.

Norden A, Persson UM and Alpizar F. 2013. Incentives, impacts, and behavioural issues in the context of payment for ecosystem services programs: Lessons for REDD+. In Bigsten A. ed. Globalisation and Development: Rethinking Interventions and Governance 120: 147.

Özler B. 2013. Do conditions moderate the effect of cash transfer programs: Preliminary findings from a systematic review. World Bank Development Impact. Accessed 20 July 2014 http:// blogs.worldbank.org/impactevaluations/do-conditionsmoderate-effects-cash-transfer-programs-preliminary-findingssystematic-review.

Özler B and Ferreira F. 2011. Conditions work! But are they a good thing? (Part II). World Bank Development Impact. Accessed 20 July 2014 http://blogs.worldbank.org/impactevaluations/ conditions-work-but-are-they-a-good-thing-part-ii.

Pagiola S. 2008. Payments for environmental services in Costa Rica. Ecological Economics 65:712-24.

Pattanayak SK, Wunder S and Ferraro PJ. 2010. Show me the money: Do payments supply environmental services in developing countries? Review of Environmental Economics 4(2):1-21.

Persson RM and Alpizar F. 2013. Conditional cash transfers and payments for environmental services: A conceptual framework for explaining and judging differences in outcomes. World Development 43:124-37.

Pham TT, Brockhaus M, Wong G, Dung LN, Tjajadi JS, Loft L, Luttrell C and Assembe Mvondo S. 2013a. Approaches to benefit sharing: A preliminary comparative analysis of 13 REDD+ countries. Working Paper 108. Bogor, Indonesia: Center for International Forestry 
Research. Accessed 30 October 2014 http://www.cifor.org/ online-library/browse/view-publication/publication/4102.html

Rawlings LB and Rubio G. 2003. Evaluating the impact of conditional cash transfer programs: Lessons from Latin America (Vol. 3119). Washington, DC: World Bank Publications.

Rodriguez LC, Pascual U, Muradian R, Pazmino N and Whitten S. 2011. Towards a unified scheme for environmental and social protection: Learning from PES and CCT experiences in developing countries. Ecological Economics 70:2163-74.

Samson M, van Niekerk I and MacQuene K. 2010. Designing and Implementing Social Transfer Programmes. Cape Town, South Africa: Economic Policy Research Institute.

Skoufias E. 2007. Poverty alleviation and consumption insurance: Evidence from PROGRESA in Mexico. Journal of Socio-Economics 35:630-49.

Soares S. 2012. Bolsa Familia, its design, its impacts and possibilities for the future. IPC-IG Working Paper 89. Brasilia, Brazil: International Policy Center for Inclusive Growth.
Soares S, Osorio RG, Soares FV, Medeiros M and Zepeda E. 2007. Conditional cash transfers in Brazil, Chile and Mexico: Impacts upon inequality. IPC Working Paper No. 35. Brasilia, Brazil: International Policy Centre for Inclusive Growth.Valencia Lomelí E. 2008. Conditional cash transfers as social policy in Latin America: An assessment of their contributions and limitations. Annual Review of Sociology 34:475-99.

Wertz-Kanounnikoff S and Angelsen A. 2009. Global and national REDD+ architecture: Linking institutions and actions. In Angelsen A, ed. Realising REDD+ National Strategy and Policy Options. Bogor, Indonesia: Center for International Forestry Research. 13-24

World Bank. 2012. Protecting the Poor and Vulnerable Households in Indonesia. Jakarta, Indonesia: World Bank.

Wunder S. 2013. When payments for environmental services will work for conservation. Conservation Letters vol 6 no. 4: 230237:1-8.

This info brief is part of a series of reviews on existing literature and practices to derive relevant lessons for the design of REDD+ benefit sharing mechanisms. The reviews aim to stimulate debate on balancing effectiveness and efficiency, while ensuring equity in ongoing policy processes in the development of REDD+ as a performance-based mechanism.

\begin{tabular}{|c|c|c|}
\hline CGIAR & $\begin{array}{l}\text { RESEARCH } \\
\text { PROGRAM ON } \\
\text { Forests, Trees and } \\
\text { Agroforestry }\end{array}$ & $\begin{array}{l}\text { This research was carried out by CIFOR as part of the CGIAR Research Program on Forests, Trees and } \\
\text { Agroforestry (CRP-FTA). This collaborative program aims to enhance the management and use of } \\
\text { forests, agroforestry and tree genetic resources across the landscape from forests to farms. CIFOR } \\
\text { leads CRP-FTA in partnership with Bioversity International, CATIE, CIRAD, the International Center for } \\
\text { Tropical Agriculture and the World Agroforestry Centre. }\end{array}$ \\
\hline
\end{tabular}

$\left.\underbrace{\text { Fd }}_{\text {CGIAR }}\right|^{\text {Fund }}$

